\title{
Bioeconomic Simulation of the Cash Flow of Rural Beef Cattle Properties with Productive, Reproductive, and Sanitary Activities
}

\author{
Yuri Braga de Shiguer Yamasaki \\ Federal University of Mato Grosso do Sul, Faculty of Veterinary Medicine and Animal \\ Science, Campo Grande, Mato Grosso do Sul, Brazil. \\ E-mail: yuri_yby@hotmail.com
}

Ricardo Carneiro Brumatti (corresponding author)

Federal University of Mato Grosso do Sul, Faculty of Veterinary Medicine and Animal Science, Campo Grande, Mato Grosso do Sul, Brazil.

E-mail: rbrumatti@gmail.com

Alberto de Oliveira Gaspar

Federal University of Mato Grosso do Sul, Faculty of Veterinary Medicine and Animal Science, Campo Grande, Mato Grosso do Sul, Brazil.

E-mail: albertogaspar_@hotmail.com

\section{Brenda Faria da Costa Leite}

Federal University of Mato Grosso do Sul, Faculty of Veterinary Medicine and Animal Science, Campo Grande, Mato Grosso do Sul, Brazil.

E-mail: brenda.farias2@hotmail.com

Rosiane Araujo Rodrigues Nass

Federal University of Mato Grosso do Sul, Faculty of Veterinary Medicine and Animal Science, Campo Grande, Mato Grosso do Sul, Brazil.

E-mail: rosiaraujo_19@hotmail.com 
Alexandre Menezes Dias

Federal University of Mato Grosso do Sul, Faculty of Veterinary Medicine and Animal

Science, Campo Grande, Mato Grosso do Sul, Brazil.

E-mail: alexandre.menezes@ufms.br

Received: Feb. 3, 2020

doi:10.5296/jas.v8i3.16365
Accepted: Apr. 27, 2020 Published: June 4, 2020

URL: https://doi.org/10.5296/jas.v8i3.16365

\begin{abstract}
This simulation study compares the technical-economic efficiency and cash flow of pasture recovery and maintenance activities, as well as improvements in mortality rate and birth rate, in different beef production systems. Three production systems were elaborated for the Cerrado biome, characterized as extensive, semi-intensive 1, and semi-intensive 2, with respective annual pasture recovery and maintenance rates of $0 \%$ and $25 \%$ for the extensive system, $5 \%$ and $25 \%$ for semi-intensive system 1 , and $7 \%$ and $33 \%$ for semi-intensive system 2. Mortality rates at weaning are $6 \%$ for the extensive system and $3 \%$ for semi-intensive systems 1 and 2 . The extensive system's gross profit was lower at US\$40471.00, followed by US\$ 41830.00 and US\$ 148669.00 for semi-intensive systems 1 and 2, respectively. Cash flow differences point to increases in the cost of forage and other nutritional inputs in semi-intensive systems 1 and 2. Economic efficiency was observed with intensification, showing that the production costs of intensive systems increased, but that these were more profitable than the extensive system with cash balance values of: extensive system US\$ 323.149; semi-intensive system 1 US\$ 405.740, semi-intensive system 2 US\$ 1213.224. Expenditure on pasture recovery and maintenance was high, but led to an increase in profitability; similarly, the improvement of mortality rates in semi-intensive systems 1 and 2 facilitated the economic viability of these systems.
\end{abstract}

Keywords: economic analysis, production system, profitability

\title{
1. Introduction
}

Beef cattle farming is a sector that contributes strongly to the national economy. Brazil produced 10.2 million tons of beef (i.e., $16 \%$ of the global production), is the largest exporter of beef (20.8\% of world exports), and owns an effective herd of around 232 million heads of cattle (USDA, 2018).

According to Deblitz (2005), beef cattle are mainly produced on pasture in Brazil, which has one of the lowest production costs compared to other countries. Further, it has requires a low capital outlay and has low operating costs. Pasture-based cattle production-unlike feedlot production systems, which are more widely used in European countries, the USA and Australia is not as dependent on grain prices, which are unstable and elastic (Torres Júnior and Aguiar, 2013). 


\section{$\triangle 1$ Macrothink}

Extensive beef production is the predominant pasture-based beef production system in the country. When there is a need for maintenance or increased production, the most commonly used resource is often the opening of new areas, instead of directing resources to existing areas that have been degraded (Dias Filho, 2011).

Because of the pressure to reduce deforestation, the increasing awareness of environmental officials, technicians, producers, and society in general, and the emergence of new technologies, producers are forced to increase pasture productivity and efficiency (Dias Filho, 2011).

Dias Filho (2014) cited that the 2006 IBGE census reported an increase in productivity, indicating that the intensification of pasture production was already taking place. The latter is evidenced by the average Brazilian stocking rate, which increased by $92 \%$ between 1975 and 2006 from 0.64 to 1.19 head per hectare. This reflects a trend towards more fertilizer and corrective pasture use on farms, coupled with more modern and efficient animal management practices (Lobato et al., 2014).

Improvements in zootechnical indices related to birth and mortality rates have a significant impact on herd growth. A reduction in calf mortality rates contributes to increased productivity, and can in most cases be achieved when simple management practices are adopted (Costa and Pacheco, 1987).

In view of this, the use of new technologies in the field is essential to escalate production. However, it is coupled with a demand for increased levels of management by technicians and producers; here, the use of simulators can guide more profitable responses to changes in herd-related practices and resource management (Ash et al., 2015). To this end, a rural property must be considered as a company, in order to reduce production costs and increase revenues by correctly defining the production process (Nantes, 2001).

A cost analysis for rural properties aims to verify their economic profitability. The correct measurement of production costs allows a clearer interpretation of the reality of the productive activity, and allows a more accurate diagnosis of the real situation of the property (Arbage, 2000). The use of cash flow in cost analysis enables the control of inputs and outputs, and demonstrates the assessment of the company's potential to generate cash; its use is essential (Marion, 2010).

This simulation study compares the technical-economic efficiency and cash flow of pasture recovery and maintenance activities, and improvements in the mortality and birth rates of different beef production systems.

\section{Material and Methods}

To structure the system, part of the bioeconomic model was used according to Brumatti et al. (2011), thus enabling the interpretation and interaction of and herd structure with cost and revenue centers. The simulator makes it possible to describe comprehensive rearing, breeding, termination, and production cycle systems for beef cattle. A fixed number of matrices enable the deterministic model to simulate the evolution of the herd on a property, with integration of its annual costs and revenues. 


\section{Macrothink}

The main calculation center of the simulator is the interaction of the herd, the productive indexes and, finally, the control centers of cost and revenue drivers, thus facilitating interaction and enabling economic values to be derived in terms of investments, revenues, costs, expenses, and profitability (Figure 1).

Through reported information on reproductive, sanitary, and zootechnical rates, the model can estimate the number of animals in the herd and their respective weights in kilograms.

These numbers influence the actual stocking rate by calculating and adjusting it to the desired stocking rate, that is, the number of animal units (UA) per expensive hectare that was proposed in each scenario. These calculations are required to determine the total quantity and the average weights for each category in the initial herd until it reaches stability, which occurs in the sixth year of system implementation.

The animal zootechnical indices, such as mortality rates and weight gain, were applied to all simulated animal categories. For reproduction rates, the birth rate proposed in each scenario was applied. Thus, the quantities obtained for each category are conditioned to the respective zootechnical indices. Once herd stability is achieved, the simulator determines the number of animals needed to simulate a fully active property.

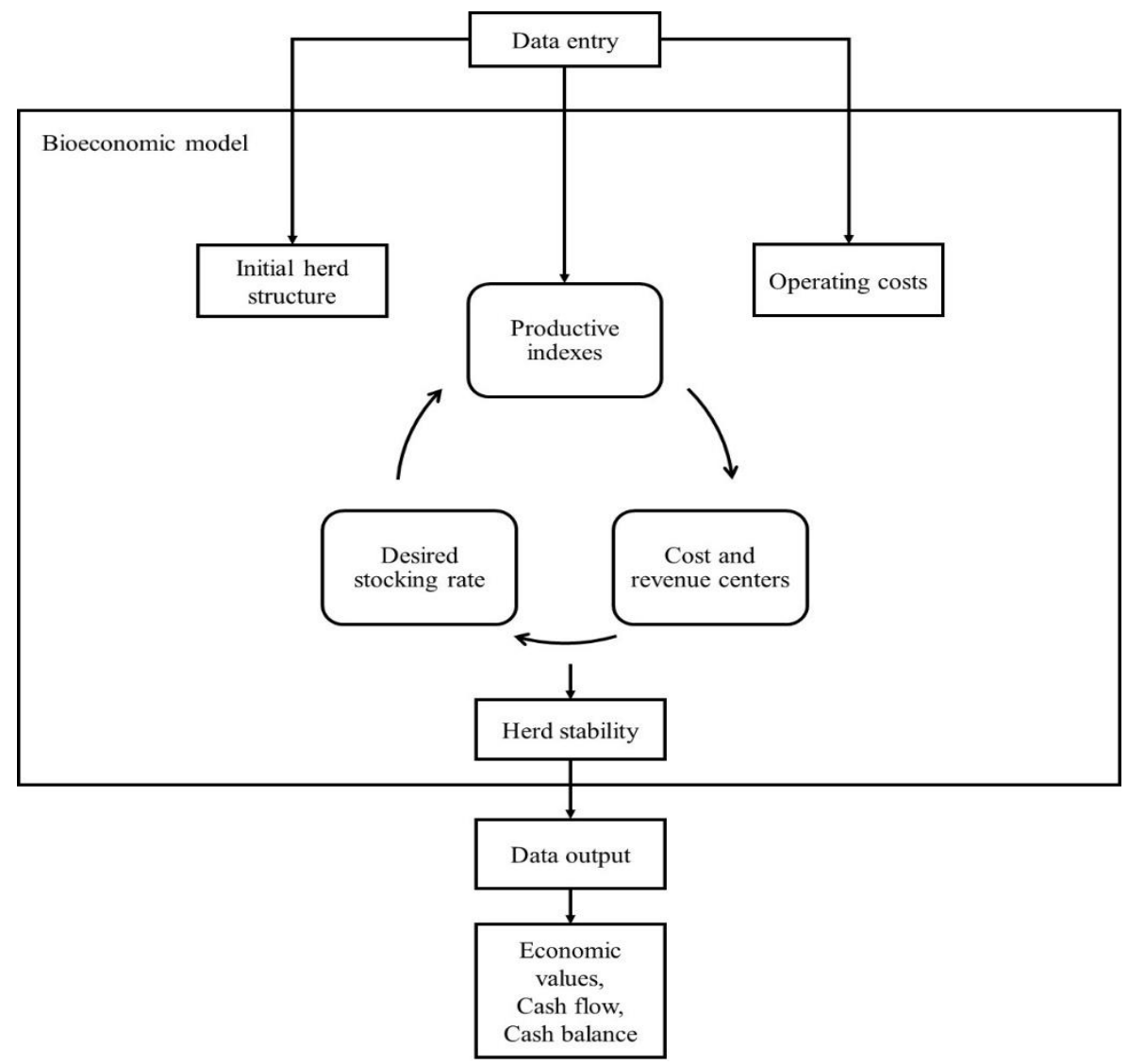

Figure 1. Flowchart of the bioeconomic model

The Gerenpec ${ }^{\circledR}$ software, developed by Embrapa Beef Cattle, was also used for analysis in order to demonstrate a coherent parameter among the bioeconomic models. 


\section{Ml Macrothink}

Journal of Agricultural Studies

ISSN 2166-0379

2020, Vol. 8, No. 3

Three beef cattle production systems were elaborated for the "Cerrado" biome, characterized as:

- Extensive system, with 401 matrices, represented by a total size of 1.500 ha, with pasture recovery of $0 \%$ and pasture maintenance of $25 \%$, with maintenance composed of manual mowing alone.

- Semi-intensive system 1, with 401 matrices, but with a total area of 1.100 ha, 5\% pasture recovery, and $25 \%$ pasture maintenance, which consists of harrowing activities, fertilization, liming, plowing, and sowing during recovery, to maintain weed mowing and control.

- Semi-intensive system 2, with an area of 1.500 ha (equivalent to the extensive system with 805 matrices), $7 \%$ pasture recovery, and 33\% pasture maintenance, which consists of harrowing, fertilizing, liming, plowing, and sowing activities during recovery, for control of weeds and pests.

The area was reduced to maintain the stocking rate and the same number of matrices; in all simulated systems, 20\% was designated as an environmental reserve, totaling 1.200 hectares of worked area in the extensive system and in the semi-intensive system 2 ; in semi-intensive system 1, the worked area was 880 ha.

The input data for the simulators were obtained from adaptations of zootechnical mean values in the region of the state of Mato Grosso do Sul (MS), collected through a literature review (Gaspar et al., 2017); the simulations illustrate the properties of this region, where the predominant biome is the Cerrado.

From the collected data, several productive indices were proposed for each evaluated scenario, as represented in Table 1.

Table 1. Average zootechnical indices of the evaluated systems

\begin{tabular}{lccc}
\hline & \multicolumn{3}{c}{ Systems } \\
\cline { 2 - 4 } \multicolumn{1}{c}{ Variables } & Extensive & Semi-intensive 1 & Semi-intensive 2 \\
\hline Birth & $70 \%$ & $80 \%$ & $80 \%$ \\
Weaning Mortality & $6 \%$ & $3 \%$ & $3 \%$ \\
Mortality other categories & $2 \%$ & $1 \%$ & $1 \%$ \\
Weight of male weaning & $159 \mathrm{~kg}$ & $196 \mathrm{~kg}$ & $196 \mathrm{~kg}$ \\
Average age of slaughter & 60 months & 24 months & 24 months \\
Male weight at slaughter & $471 \mathrm{~kg}$ & $476 \mathrm{~kg}$ & $476 \mathrm{~kg}$ \\
Culling cow & $20 \%$ & $20 \%$ & $20 \%$ \\
Stocking Rate (UA/ha) & 0,8 & 1,2 & 1,2 \\
Pasture Recovery Annual Rate & $0 \%$ & $5 \%$ & $7 \%$ \\
Pasture Maintenance Annual Fee & $25 \%$ & $25 \%$ & $33 \%$ \\
\hline
\end{tabular}

Source: adapted from Gaspar et al. (2017).

The nutritional management of the herd varied according to the system under assessment: the extensive system included only mineral supplementation for the entire herd. In addition to mineral salt, semi-intensive systems 1 and 2 included protein and mineral supplementation 


\section{Ml Macrothink}

Journal of Agricultural Studies

ISSN 2166-0379

2020, Vol. 8, No. 3

for female and male breeding categories, with an estimated intake of $450 \mathrm{~g} / \mathrm{UA} /$ day over a period of 120 days.

The applied sanitary and reproductive management practices were standardized, with all systems adopting the same techniques during the same periods. Sanitary management consisted of the control foot and mouth disease, brucellosis, leptospirosis, clostridiosis, rabies, ticks, and mosquitoes. Machine use and improvements were also standardized for all simulated systems. The workforce was adjusted to the herd size of each property, based on a ratio of 1.000 animals per employee. However, in the extensive system, the weaning and adult mortality rates were changed to observe the impact of this change on this system.

The revenue for the simulated systems was obtained from the sale of finished animals. The USA dollar was used as currency for analysis; it was set at $\mathrm{R} \$ 3.81$, based on exchange rates for the period May to October 2018, according to the Central Bank of Brazil. For the financial analysis, the costs to implement pasture-based activities were considered as the investment value.

Once all scenarios were elaborated, it was possible to generate an income statement that indicated the gross profit and gross margin.

The income statement and operating cash flows for each proposed scenario made economic analyses possible.

\section{Results and Discussion}

The herd structure of the simulated systems indicates that intensification of ownership leads to an increase in the number of animals. This can partly be explained by the number of matrices in each simulated scenario: 401 matrices in the extensive system, 401 in semi-intensive system 1, and 805 in semi-intensive system 2 (Table 2).

Table 2. Herd structure of extensive, semi-intensive 1, and semi-intensive 2 systems

\begin{tabular}{lccc}
\hline & \multicolumn{3}{c}{ Systems } \\
\cline { 2 - 4 } \multicolumn{1}{c}{ Category } & Extensive & Semi-intensive 1 & Semi-intensive 2 \\
\hline Total matrices & 401 & 401 & 805 \\
Calves & 264 & 312 & 624 \\
Growing female (14, 24 e 36m) & 195 & 237 & 475 \\
Growing male (Young bulls) & 395 & 305 & 613 \\
Fattening 24m & - & 21 & 42 \\
Fattening 36m & 3 & 104 & 209 \\
Fattening 48m & 17 & 21 & 42 \\
Fattening 60m & 106 & 3 & 6 \\
Sires & 16 & 13 & 27 \\
Total & 1.397 & 1.417 & 2.843 \\
\hline
\end{tabular}

Acronym "m" corresponds to months.

The increase in the total herd, mainly justified by the use of correctives and fertilizers in addition to the correct management of the productive system, result in increased pasture 
support capacity and improvements in the zootechnical indices. In the extensive system, a smaller amount of product was evidenced, mainly in the brood category; this is justified by the higher weaning mortality rate compared to other scenarios (Table 2).

As a result of these better zootechnical indices for birth rate and weaning mortality rate in semi-intensive systems 1 and 2, there was an increase of $18 \%$ and $136 \%$, respectively, in the number of brood stock produced in the herd (48 and 360 more calves in semi-intensive systems 1 and 2, respectively) compared to the extensive system.

Such production increases led to increases in the stock values of these animal categories, by US\$ 16058.59 and US\$ 120439.44 for semi-intensive systems 1 and 2, respectively, relative to the 2017 market values.

This result was also observed by evaluating the three systems using Embrapa beef cattle Gerenpec ${ }^{\circledR}$ software, showing an increase of $14.3 \%$ and $130 \%$ in the offspring produced in semi-intensive systems 1 and 2, respectively, relative to the extensive system.

The results are corroborated by the observations of Corrêa et al. (2006), whose simulated evaluations of improved beef cattle production systems indicated that the number of breeders and the total herd size increased as the farm intensified.

In the analysis of the total simulated herd size, semi-intensive system 2 presents an increase of $103.5 \%$ (1.446 more animals) relative to the extensive system. In semi-intensive system 1 , this increase was only $1.4 \%$ (20 more animals) relative to the extensive system, making the improved systems more biologically efficient.

A computational evaluation performed by Beretta et al. (2001) to estimate the productivity and biological efficiency of three beef cattle systems, with differing production improvement approaches that focus on age at first calving and birth rates, showed that the proportion of cows in stock increased with an increased birth rate. In summary, extreme situations of a low birth rate $(50 \%)$ and high calving age (four years) resulted in a herd structure where only $33 \%$ of the stock corresponds to calves they conceive. On the other hand, high birth rates $(90 \%)$ and a low calving age (two years) resulted in herds with $81 \%$ of calves calving each year. In the same study, it was observed that the number of breeders that were needed to maintain a production of 50 calves per year decreased as the production systems intensified; this was coupled with a decrease in the relative importance of failed cows and replacement heifers, which occurred when the birth rate increased.

Abreu et al. (2003) also observed higher calf production due to a birth rate increase from 65 to $75 \%$; this increase in the number of cows and calves was gradual during the first four simulated years. Their finding is similar to this study, and demonstrates that differences in live weight production per area and biological efficiency between systems result from changes in herd structure and land use.

The economic analysis results for the different scenarios are outlined in Table 3. 
Table 3. Statement of economic results of simulated production systems

\begin{tabular}{|c|c|c|c|c|c|c|}
\hline \multirow{2}{*}{ Items } & \multicolumn{2}{|c|}{ Extensive system } & \multicolumn{2}{|c|}{ Semi-intensive system 1} & \multicolumn{2}{|c|}{ Semi-intensive system 2} \\
\hline & U\$ & $\%$ & U\$ & $\%$ & U\$ & $\%$ \\
\hline \multicolumn{7}{|l|}{ Revenue } \\
\hline Beef cattle & 77842 & $55.4 \%$ & 97653 & $54.1 \%$ & 195923 & $54.1 \%$ \\
\hline Fat cow & 32582 & $23.0 \%$ & 44.380 & $24.6 \%$ & 89041 & $24.6 \%$ \\
\hline Heifers & 29196 & $20.6 \%$ & 36192 & $20.0 \%$ & 72613 & $20.0 \%$ \\
\hline Bulls & 1.802 & $1.2 \%$ & 2.002 & $1.1 \%$ & 4.016 & $1.1 \%$ \\
\hline Gross revenue & 141421 & & 180227 & & 361593 & \\
\hline \multicolumn{7}{|l|}{ Costs } \\
\hline \multicolumn{7}{|l|}{ Inputs } \\
\hline Fodder & 2.092 & $1.4 \%$ & 27924 & $15.4 \%$ & 56905 & $15.7 \%$ \\
\hline Nutritionals & 10567 & $7.4 \%$ & 16924 & $9.3 \%$ & 32011 & $8.8 \%$ \\
\hline Reproductive & 7.680 & $5.4 \%$ & 8.256 & $4.5 \%$ & 16060 & $4.4 \%$ \\
\hline Toilets & 3.842 & $2.7 \%$ & 4.431 & $2.4 \%$ & 6.875 & $1.9 \%$ \\
\hline Total inputs & 24182 & $17.0 \%$ & 57535 & $31.9 \%$ & 111851 & $30.9 \%$ \\
\hline Employees & 23432 & $16.5 \%$ & 23064 & $12.7 \%$ & 34021 & $9.4 \%$ \\
\hline Maintenance* & 7.315 & $5.1 \%$ & 7.315 & $4.0 \%$ & 7.311 & $2.0 \%$ \\
\hline Effective operating costs & 57578 & $40.7 \%$ & 90486 & $50.2 \%$ & 155753 & $43.0 \%$ \\
\hline Depreciation & 19347 & $13.6 \%$ & 19347 & $10.7 \%$ & 19336 & $5.3 \%$ \\
\hline Total operating costs & 76.925 & $54.3 \%$ & 109833 & $60.9 \%$ & 175089 & $48.4 \%$ \\
\hline Remuneration & 15.739 & $11.2 \%$ & 15739 & $8.7 \%$ & 15730 & $4.3 \%$ \\
\hline Administrative costs & 1.889 & $1.3 \%$ & 2.203 & $1.2 \%$ & 2.517 & $0.6 \%$ \\
\hline Taxes & 6.397 & $4.5 \%$ & 10620 & $5.8 \%$ & 19588 & $5.4 \%$ \\
\hline Total costs & 100.950 & $71.3 \%$ & 138395 & $76.7 \%$ & 212924 & $58.8 \%$ \\
\hline Gross profit & 40.471 & & 41830 & & 148669 & \\
\hline Gross margin & & $28.6 \%$ & & $23.2 \%$ & & $41.1 \%$ \\
\hline
\end{tabular}

* Maintenance of machinery, equipment, and fuel.

The total annual farm cost shows a significant increase with the intensification of production systems, from US\$ 100950 in the extensive system to US\$ 138395 and US\$ 212924 in semi-intensive systems 1 and 2, respectively. This increase is due to the more intensive use of inputs (mainly from pasture fertilizers).

Revenues from the improved systems increase according to the degree of intensification, with revenues from semi-intensive systems 1 and 2 of US\$ 180227 and US\$ 361593.00, respectively, which are significantly higher than the revenue from the extensive system of US\$ 141421. The higher revenues are explained by the higher number of animals sold, thus contributing to gross revenue. The same was observed in the simulation performed with 


\section{Macrothink

Gerenpec ${ }^{\circledR}$ software, where semi-intensive system 2 had a revenue of US\$ 361034.00, followed by semi-intensive system 1 with US\$ 179999.00 and, lastly, the extensive system with US\$ 135651.00. Note that all revenues are sufficient to cover the total costs presented. This same impact was observed in the work done by Abreu et al. (2003), which showed that the decrease in calf mortality rates caused a 5.12\% revenue increase from scenario 1 to scenario 2.

Table 3 further indicates that the gross profit from the smaller extensive system is US\$ 40471, followed by semi-intensive systems 1 and with US\$ 41830 and US\$148669, respectively, showing that the most technology-intensive systems are more profitable. In semi-intensive system 1 and 2, there was a higher effective operating cost, mainly pasture costs; however, the gross revenue generated in these systems covered the costs.

Compared to the simulated gross margin in Gerenpec $®$, semi-intensive system 2 has a margin of US\$13758/ha, followed by semi-intensive system 1 with US\$ 55.49/ha, and the extensive system with US\$ 48.79/ha.

The same was observed by Corrêa et al. (2006), who analyzed several improved systems (with correct pasture management and similar zootechnical indices for the semi-intensive systems analyzed); the profit and gross margin obtained were higher than for the modal system.

It is noted that the cost of sanitary inputs was relatively small in all systems compared to other costs, accounting for approximately $2.5 \%$ of the effective operating cost.

Cash flow allows us to observe the company's situation on a monthly basis, not only at year-end, as each production system has its peculiarities over the period.

In the cash flow analysis of the extensive system, it is noted that the system works with a negative balance for 3 months (January, February, and March). The negative cash flow during these 3 months was characteristic of the sales concentration of animals in different periods (Figure 2 and 3). This same variability of cash flow between months and years in livestock activity is observed by Scott et al. (2013a) in a study on profitability in 3 livestock management systems. 


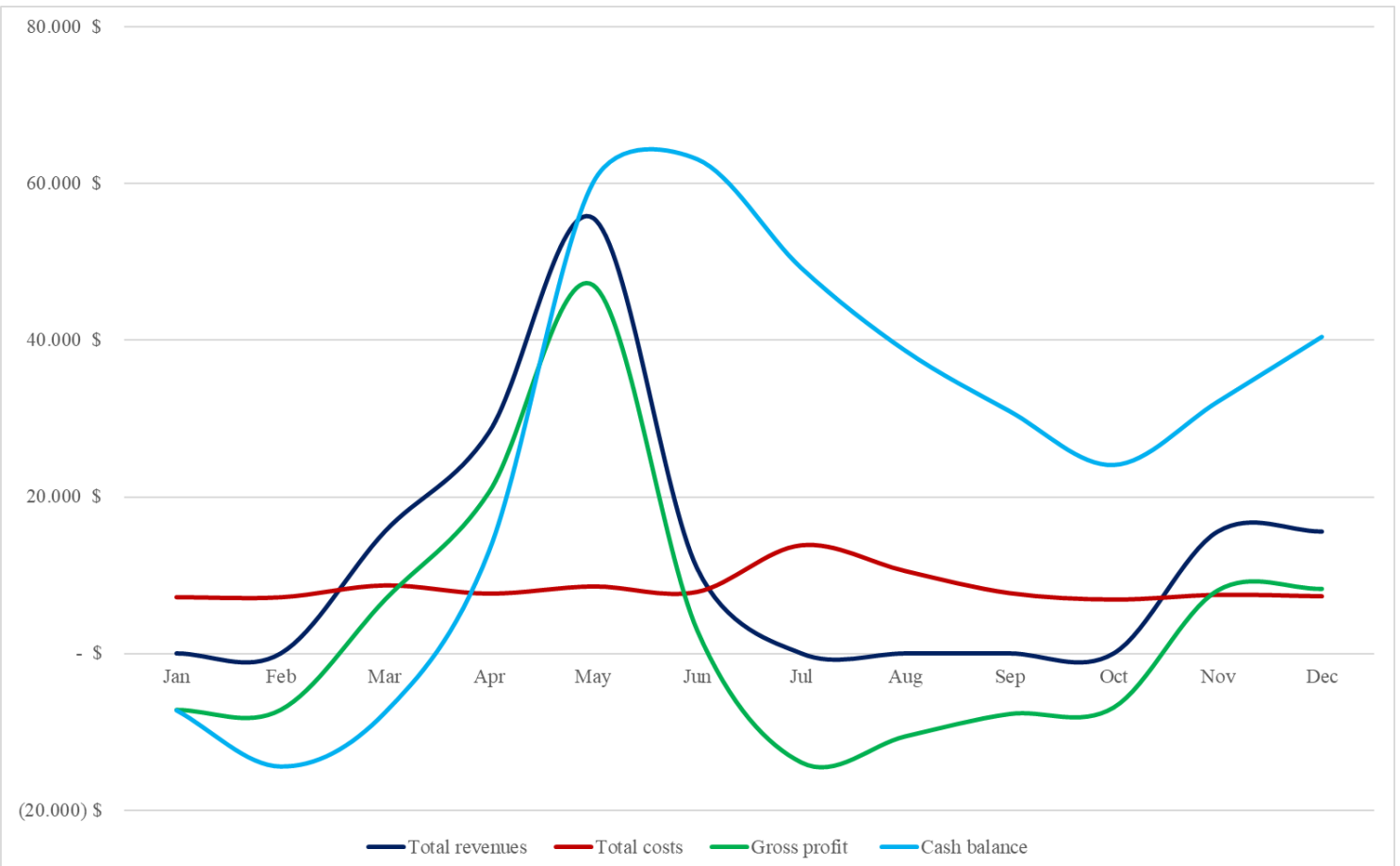

Figure 2. Cash flow and cash balance in the extensive system (birth rate of $70 \%$, weaning mortality rate of $6 \%$ and pasture recovery of $0 \%$ and pasture maintenance of $25 \%$ )

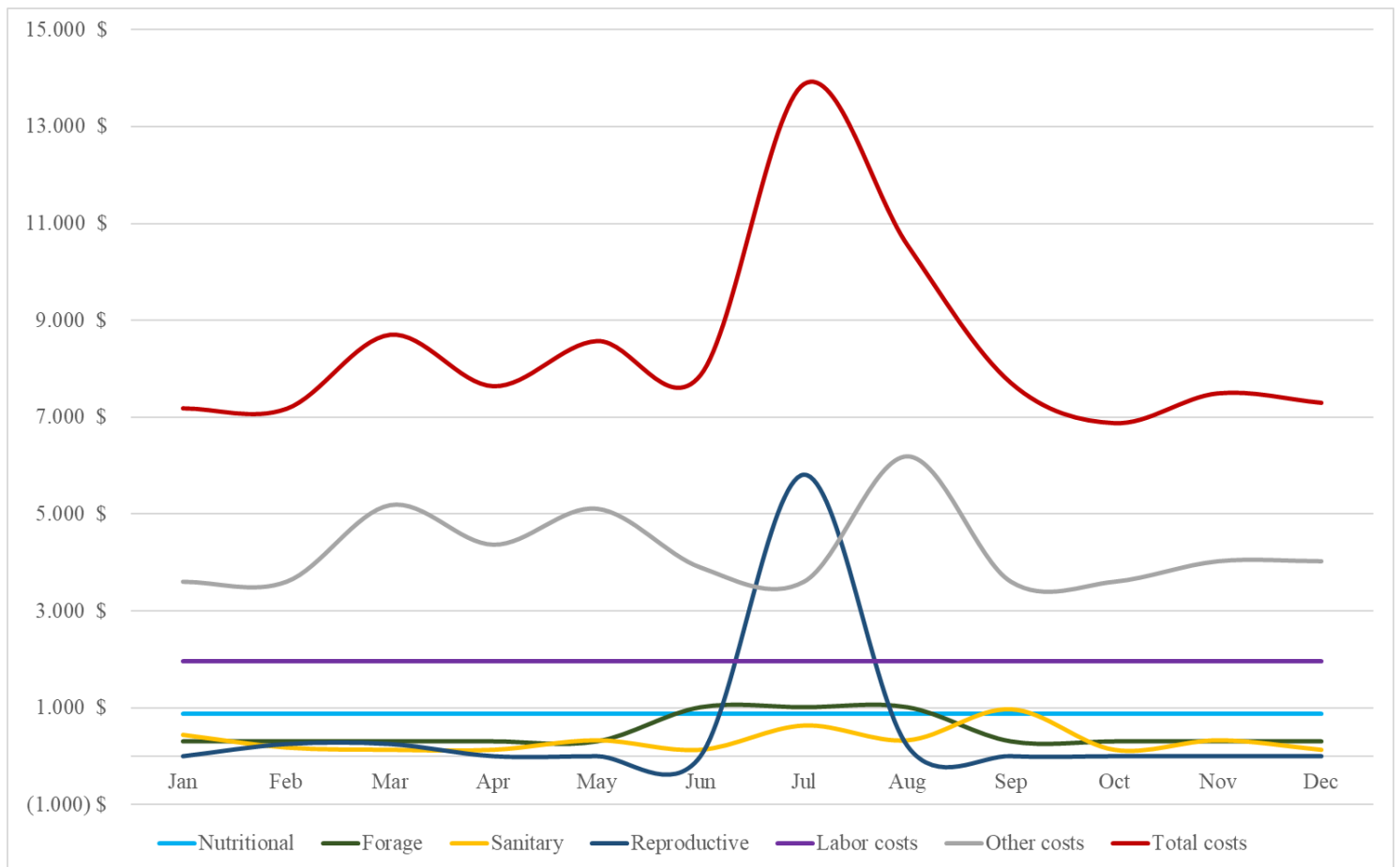

Figure 3. Extensive system costs profile in 12 months (costs nutritional, forage, sanitary, reproductive, labor, other costs and total costs)

* Other Costs: Entrepreneur Profit, Depreciation, Administrative and Financial Expenses, Taxes and Fees. 
Semi-intensive system 1 presented a negative cash balance during the first 3 months of the year, but its recovery was not as significant as semi-intensive system 2 . In all months of the year, a higher gross revenue was obtained from the semi-intensive system, which is sufficient to contribute to its higher profitability compared to the extensive system (Figure 4).

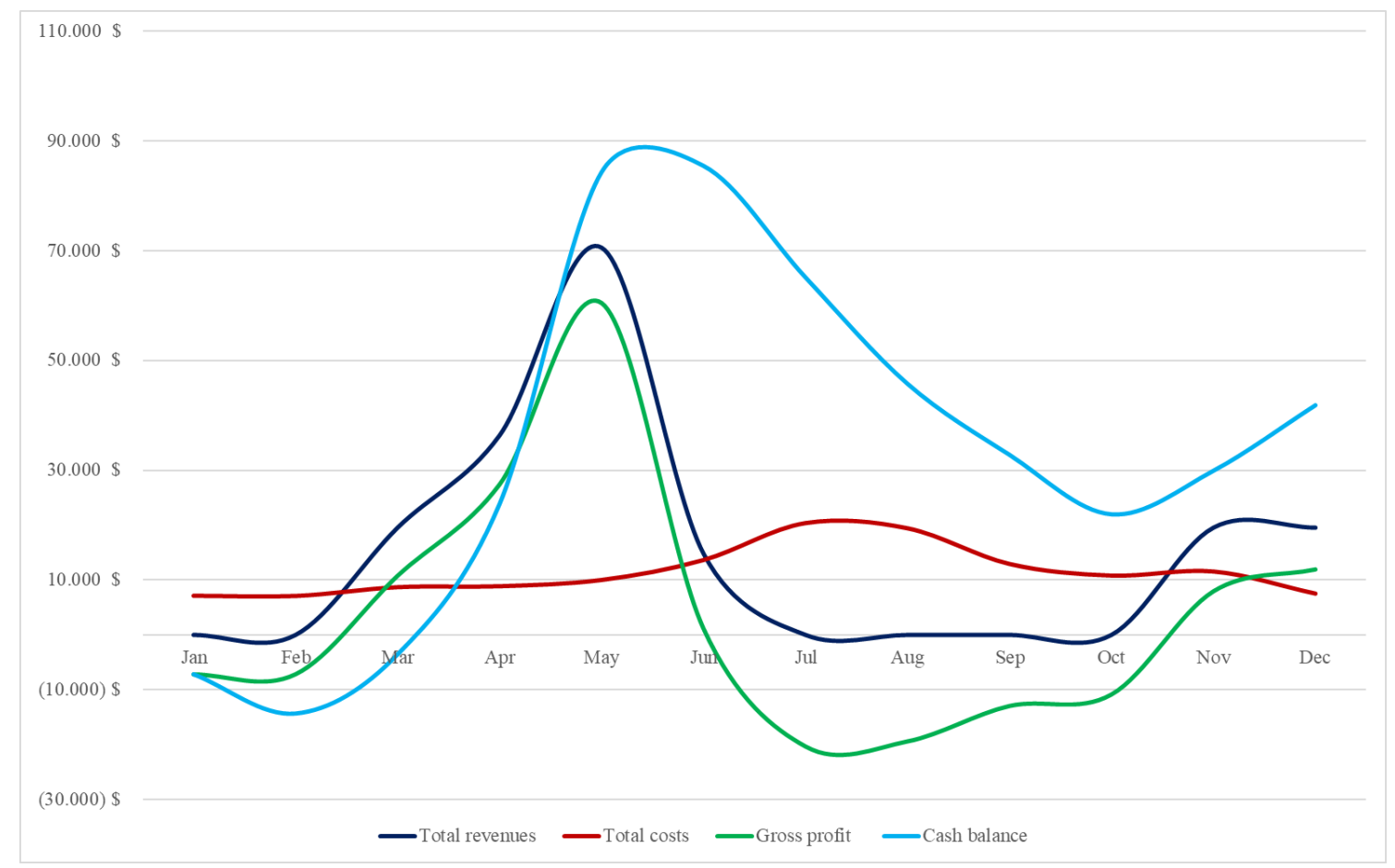

Figure 4. Cash flow and cash balance of semi-intensive system 1 (birth rate of $80 \%$, weaning mortality rate of $3 \%$ and pasture recovery of $5 \%$ and pasture maintenance of $25 \%$ )

It should be noted that the forage costs in semi-intensive systems 1 and 2 were higher compared to the extensive system $(1.47 \%)$, at $15.4 \%$ and $15.7 \%$, respectively. These cash flow differences from the two technology-intensive systems are shown in Figures 5 and 7.

In a study conducted by the International Sustainability Institute (2015), in economic analysis of three simulated livestock scenarios (without intensification; scenario with technical assistance; scenario with technical assistance and intensification of $20 \%$ of pasture areas) varying the size of the pasture area (300, 500, 1.000 and 4.000 hectares), there was an increase in the size of the pasture area in an area of 1.000 hectares of pasture, there was an increase in costs in the most technical scenarios (US\$ 14452980, US\$ 17016313, US\$ 20027486 respectively), however, in observation of the cash balance, the most technical scenarios were more profitable, with a cash balance of US\$ 14620837, US\$ 20986368, US\$ 40389459, respectively.

Yokoyama et al. (1999), which analyzed cash flow, expenses, and revenues in different pasture renewal systems, showed that there is an increase in revenue in the first year of pasture recovery, but that significant increases in revenue are generated from the second year onwards. The authors concluded that pasture recovery emerges as an economically viable activity, because it increases stocking and weight gain in recovered pastures. 


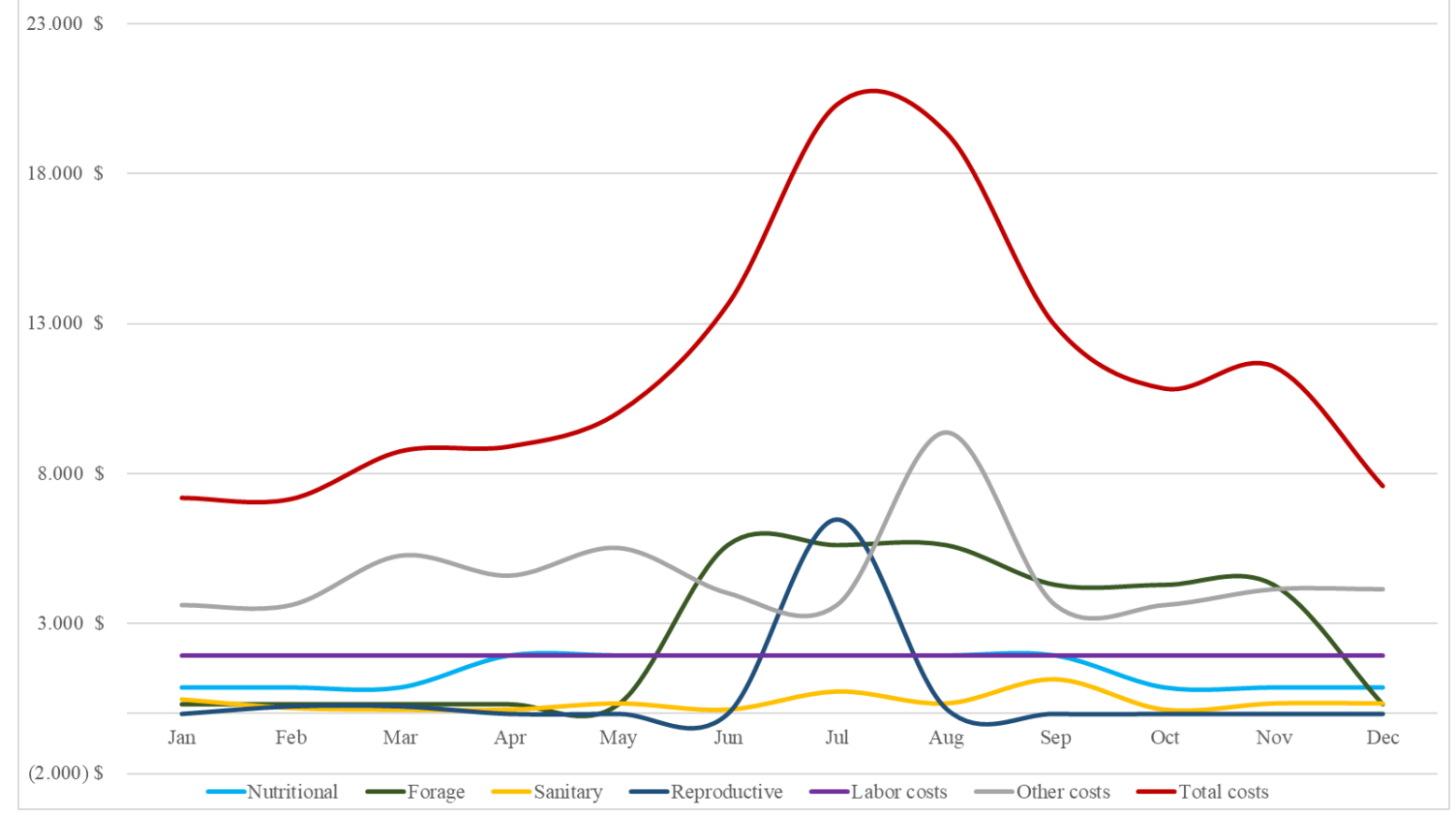

Figure 5. Semi-intensive system 1 costs profile in 12 months (costs nutritional, forage, sanitary, reproductive, labor, other costs and total costs)

* Other Costs: Entrepreneur Profit, Depreciation, Administrative and Financial Expenses, Taxes and Fees.

The balance of semi-intensive system 2 showed the same behavior, but increased along with the gross profit throughout the year, relative to the extensive system and semi-intensive system 1 (Figure 6). The cash flow reflects a significant difference in the share of revenue in the system, and a large difference in fodder expenditure (Figures 6 and 7). 


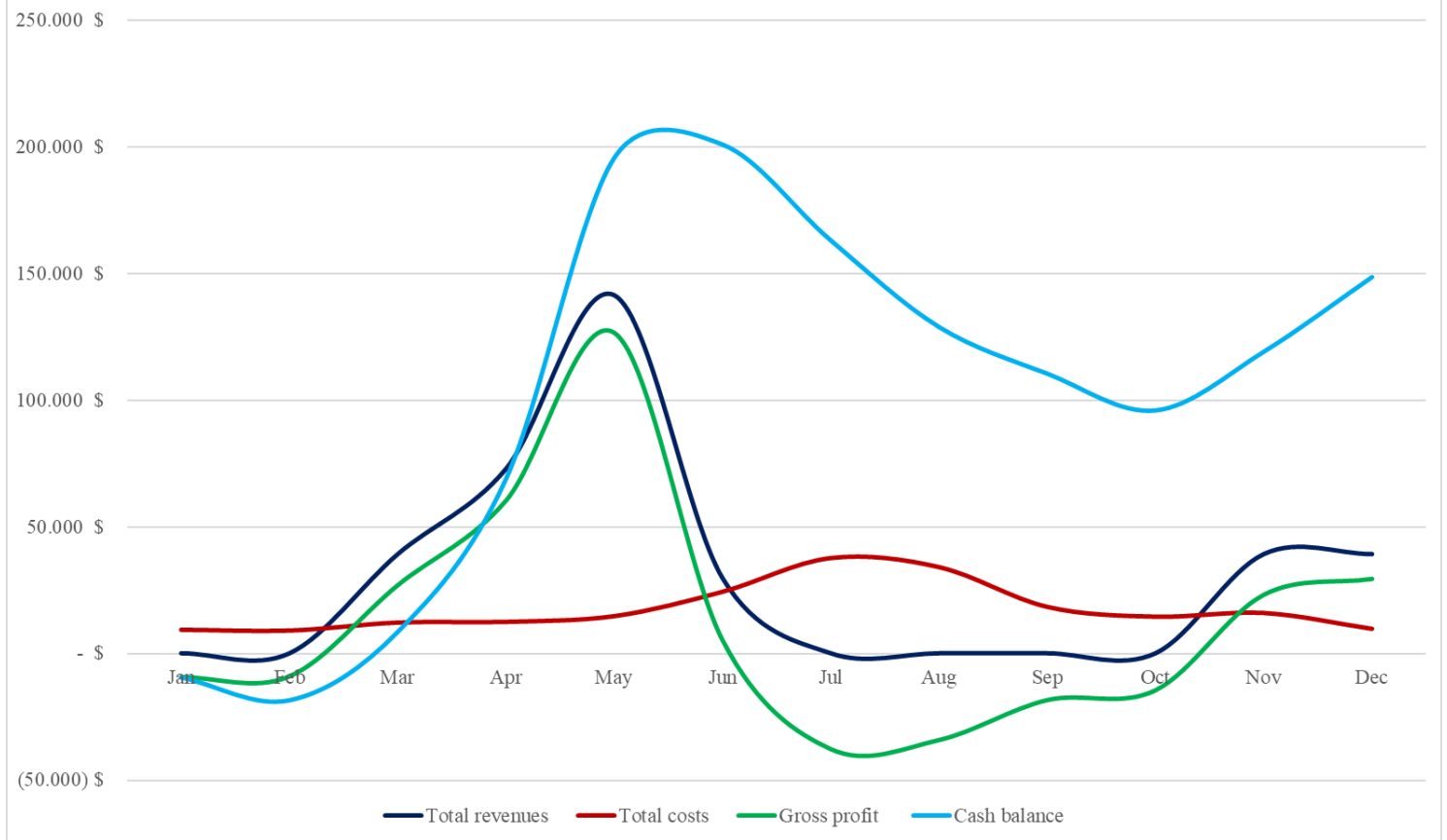

Figure 6. Cash flow and cash balance of semi-intensive system 2 (birth rate of $80 \%$, weaning mortality rate of $3 \%$ and pasture recovery of $7 \%$ and pasture maintenance of $33 \%$ )

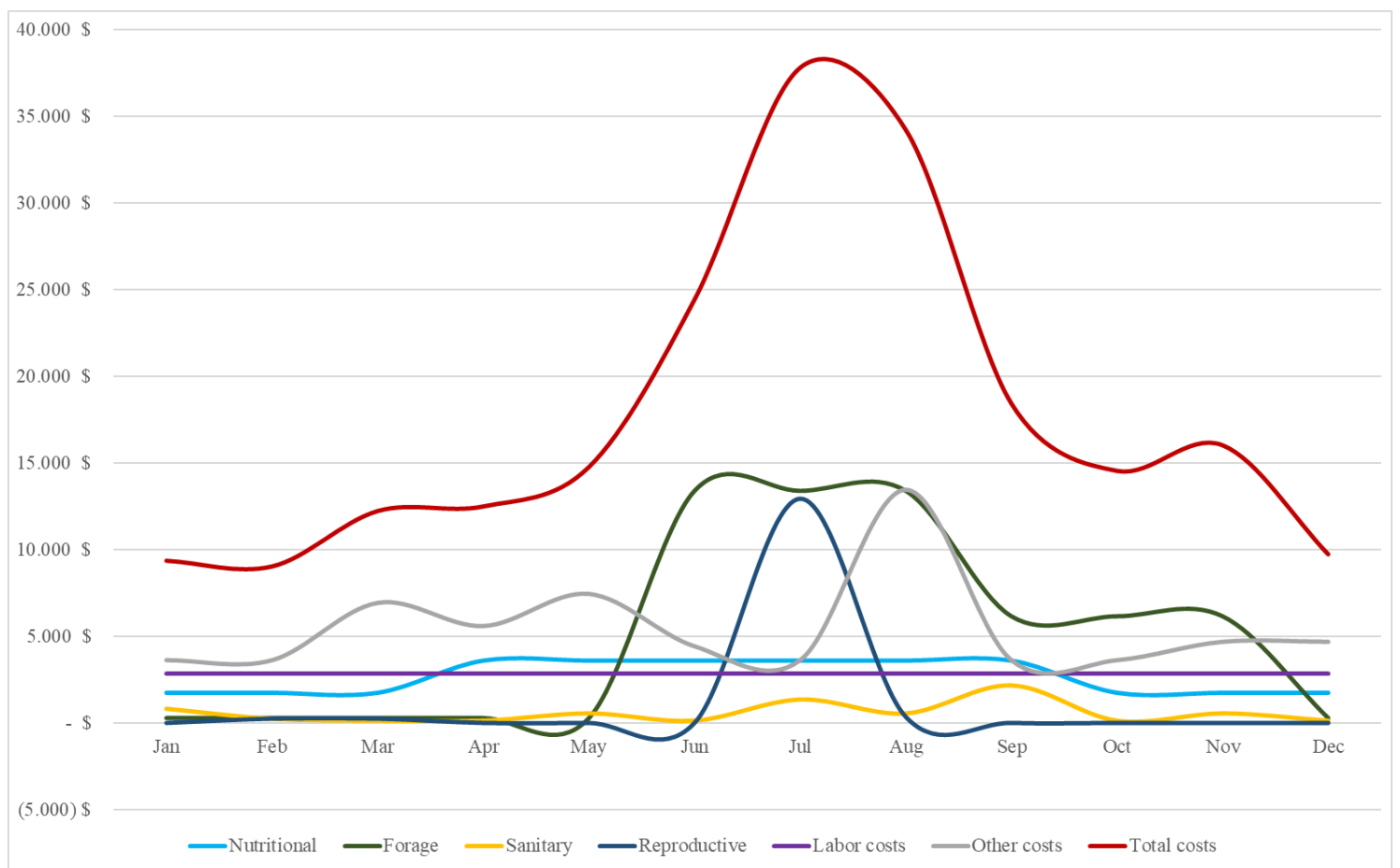

Figure 7. Semi-intensive system 2 costs profile in 12 months (costs nutritional, forage, sanitary, reproductive, labor, other costs and total costs)

* Other Costs: Entrepreneur Profit, Depreciation, Administrative and Financial Expenses, Taxes and Fees.

The fluctuation in annual revenue could be resolved by distributing the revenue over the 
years; further, it is possible to vary a rural property's production (Viana et al., 2006). Alternatively, according to Macedo (2009), grain supplementation could be offered to animals in the most critical months of livestock production, thus obtaining more constant annual revenues.

An analysis of the cash balance of the three simulated scenarios indicates that semi-intensive system 2 started the year with a significantly lower cash balance than the other scenarios. This is mainly attributable to high input costs - mainly forage and other nutritional expenses; however, its balance remained positive and increased significantly from March onwards.

The extensive system had a slightly higher cash balance in January and February compared to semi-intensive system 1; however, semi-intensive system 1 had a relatively larger cash balance compared to the extensive system from March onwards. This behavior is linked to the highest total cost in semi-intensive system 1 in January and March, which consequently impacted on this scenario's cash balance. However, semi-intensive system 1 had a higher cash balance in most months of the year compared to the extensive system; this difference is particularly visible in April, May, June, July, and August (Figure 8).

This behavior was observed in the study conducted by Scott et al. (2013b), evaluating the economic risk of different livestock management systems in three scenarios, showed a scenario with a higher accumulated cash balance due to a higher level of production, was also the scenario with the highest cost of fertilizer maintenance of pasture (pasture reform rate at $4 \%$ per year).

Silva (2012) indicates that it is important to keep cash inflows and outflows under control, and to know periods of negative cashflow in advance; this allows expenses on peak production inputs to be delayed for future payment.

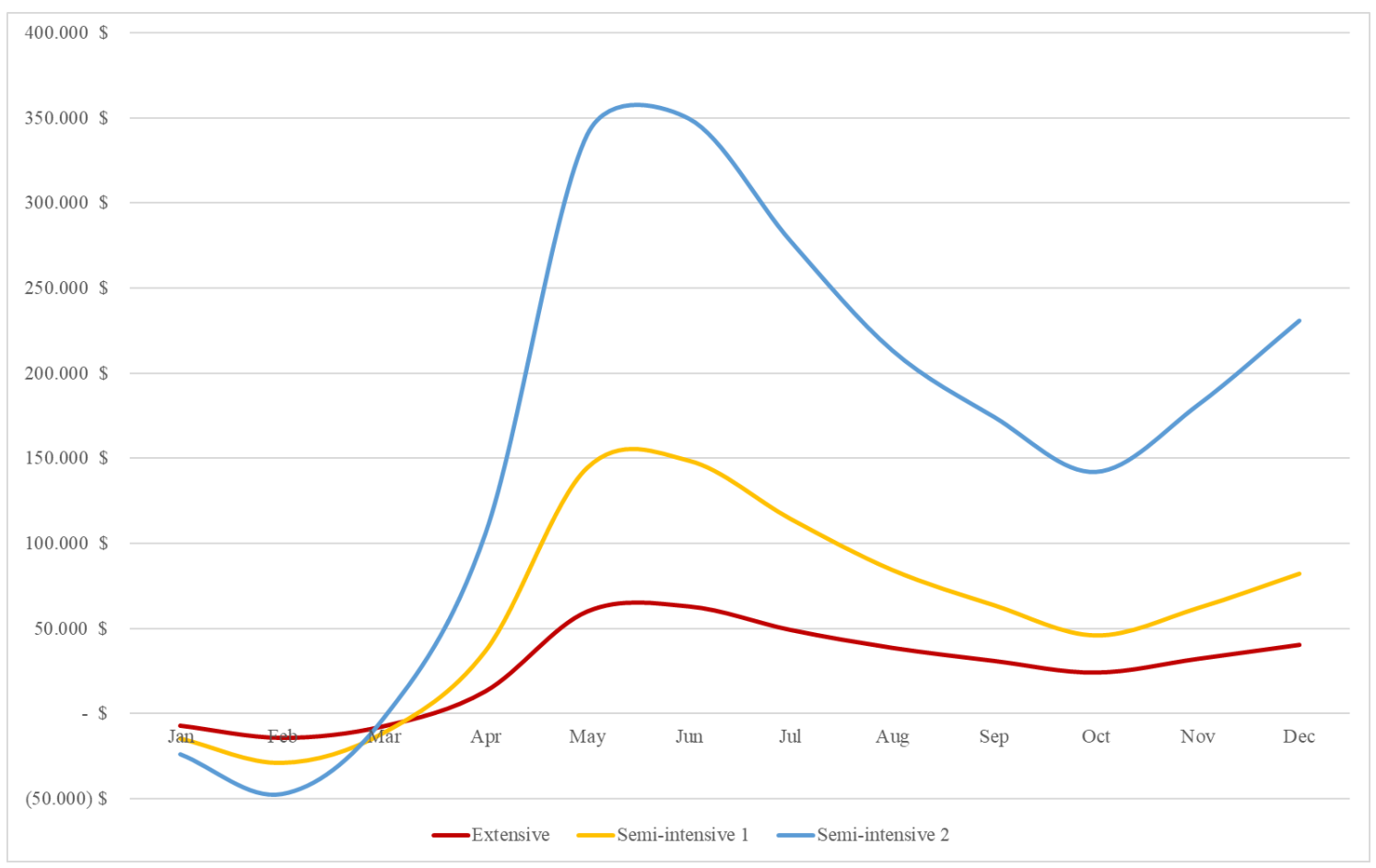

Figure 8. Cash balance of the extensive, semi-intensive and semi-intensive 2 systems 


\section{Conclusion}

The economic results of the three production systems of beef cattle simulated in this study show that the semi-intensive systems 1 and 2, characterized by better applicability of production techniques (average age of slaughter, stocking rate, pasture recovery and maintenance annual rate), lower mortality rates and higher birth rates were more profitable than the extensive system, with annual cash balance values of US\$ 405.740, US\$ 1213.224, US\$ 323.149 respectively. Demonstrating that improvements in technical and technological conditions reflect higher production costs as demonstrated in the cash flow of the 3 scenarios evaluated, but these improvements increase productivity, consequently resulting in higher revenues, overllaping production costs in the scenarios analyzed.

\section{Acknowledgements}

This study was financed in part by the Coordenação de Aperfeiçoamento de Pessoal de Nível Superior - Brasil (CAPES) - Finance Code 001, the Federal University of Mato Grosso do Sul, and the Science and Technology Development Support Foundation (FUNDECT / MS).

\section{References}

Abreu, U. G. P., Cezar, I. M., \& Torres, R. A. (2003). Análise Bioeconômica da Introdução de Período de Monta em Sistemas de Produção de Rebanhos de Cria na Região do Brasil Central. $\begin{array}{llll}\text { Revista Brasileira } \quad \text { Zootecnia, } & 32, & 1198-1206 .\end{array}$ https://doi.org/10.1590/S1516-35982003000500021

Arbage, A. P. (2000). Economia rural: conceitos básicos e aplicações. Chapecó: Universitária Grifos, 305.

Ash, A., Hunt, L., McDonald, C., Scanlan, J., Bell, L., Cowley, R., ... MacLeod, N. (2015). Boosting the productivity and profitability of northern Australian beef enterprises: Exploring innovation options using simulation modelling and systems analysis. Agricultural Systems, 139, 50-65. https://doi.org/10.1016/j.agsy.2015.06.001

Barbosa, F. A., \& Souza, R. C. (2007). Administração de fazendas de bovinos - leite e corte. Viçosa: Aprenda Fácil, 342.

Barros, G. S. C., Adami, A. C. O., \& Zandoná, N. F. (2014). Embarques dos produtos do agronegócio recuam em 2014. CEPEA/ESALQ. Available: http://www.cepea.esalq.usp.br/comunicacao/Cepea_ExportAgro_2014.doc.

Beretta, V., Lobato, J. F. P., \& Netto, C. G. A. M. (2001). Produtividade e eficiência biológica de sistemas pecuários de cria diferindo na idade das novilhas ao primeiro parto e na taxa de natalidade do rebanho no Rio Grande do Sul. Revista Brasileira de Zootecnia, 30, 1278-1286. https://doi.org/10.1590/S1516-35982001000500022

Botteon, R. C. C. M., Botteon, P. T. L., Santos Júnior, J. C. B., Pinna, M. H., \& Lóss, G. C. (2008). Frequiência de diarréia em bezerros mestiços sob diferentes condições de manejo na região do médio Paraíba - Rio de Janeiro e Minas Gerais. Brazilian Journal of Veterinary $\begin{array}{llll}\text { Research Animal } & \text { Science, } & \text { 153-160. }\end{array}$ 
https://doi.org/10.11606/issn.1678-4456.bjvras.2008.26712

Brumatti, R. C., Ferraz, J. B. S., Eler, J. P., \& Formigonni, I. B. (2011). Desenvolvimento de índice de seleção em gado de corte sob o enfoque de um modelo bioeconômico. Archivos de Zootecnia, 60, 205-213. https://doi.org/10.4321/S0004-05922011000200005

Carvalho, L. C. S., Elia, B. S., \& Decotelli, C. A. (2009). Matemática Financeira Aplicada. 1a. ed. FGV, 160.

Cerri, C. C., Moreira, C. S., Alves, P. A., Raucci, G. S., Castigioni, B. A., Mello, F. F. C., ... Cerri, C. E. P. (2016). Assessing the carbono footprint of beef cattle in Brazil: a case study with 22 farms in the state of Mato Grosso. Journal of Cleaner Production, 112, 2593-2600. https://doi.org/10.1016/j.jclepro.2015.10.072

Corrar, L. J. (2004). Pesquisa Operacional: para decisão em contabilidade e administraçãocontabiliometria. São Paulo: Atlas, 458.

Corrêa, E. S., Costa, F. P., Melo Filho, G. A., \& Pereira, M. A. (2006). Sistemas de produção melhorados para gado de corte em Mato Grosso do Sul. Comunicado técnico/Embrapa Gado de Corte. 102, Campo Grande, MS, 11.

Costa, F. P., \& Pacheco, J. A. C. (1987). Importância das taxas de natalidade e mortalidade de bezerros no crescimento de um rebanho bovino de corte. Revista da Sociedade Brasileira de Zootecnia, Viçosa, 16, 465-469.

Costa, L. B., Ceretta, P. S., \& Gonçalves, M. B. F. (2006). Viabilidade econômica: análise da bovinocultura de corte. Informativo econômico, 26, 26-38.

Crepaldi, S. A. Contabilidade Rural: Uma abordagem decisorial. (2009). 5. ed. São Paulo: Atlas, 456.

De Zen, S., Correr, G., \& Santos, M. (2015). Alta do bezerro reduz poder de compra de recriador para pior resultado em 16 anos. Informativo CEPEA/ESALQ. Available: http://cepea.esalq.usp.br/boi/informativos/2015/01BRJan_Mar.pdf

De Zen, S., Moreira, R., Gomes, M., \& Bettiol, G. (2017). Queda no preço do bezerro limita alta do COT em 2016. Informativo CEPEA/ESALQ 2017. Available: https://www.cepea.esalq.usp.br/upload/revista/pdf/0704395001510660853.pdf

Deblitz, C. (2005). International farm comparison network. In: International farm managemente congress, 15, Campinas. Proceedings.

Dias Filho, M. B. (2011). Os desafios da produção animal em pastagens na fronteira agrícola brasileira. Revista Brasileira de Zootecnia, 40, 243-252.

Dias Filho, M. B., Sambuichi, R. H. R., Silva, A. P. M., Oliveira, M. A. C., \& Savian, M. (2014). Recuperação de pastagens degradadas na Amazônia: desafios, oportunidades e perspectivas. In: Políticas agroambientais e sustentabilidade: desafios, oportunidades e lições aprendidas. Brasília, DF: Ipea. 149-169. https://doi.org/10.13140/rg.2.1.1854.5761 
Dill, M. D., Emvalomatis, G., Saatkamp, H., Rossi, J. A., Pereira, G. R., \& Barcellos, J. O. J. (2015). Factors affecting adoption of economic management practices in beef cattle production in Rio Grande do Sul state, Brazil. Journal of Rural Studies, 42, 21-28. https://doi.org/10.1016/j.jrurstud.2015.09.004

Dutra, I. S. (2007). Proposta preliminar para a implantação de um sistema de certificação sanitária de propriedades rurais produtoras de carne bovina e bubalina e de leite. Unesp Araçatuba.

Gaspar, A. O., Brumatti, R. C., Dias, A. M., \& Arruda, L. A. (2017). Bioeconomic simulation of productive systems in beef cattle production activities which emphasis in maintenance and pasture recovery. Archivos de Zootecnia, 66, 485-490. https://doi.org/10.21071/az.v66i256.2763

Godber, O. F., \& Wall, R. (2014). Livestock and food security: vulnerability to population growth and climate change. Global Change Biology, 20, 3092-3102. https://doi.org/10.1111/gcb.12589

Gottschall, C. S., Canellas, L. C., Almeida, M. C., Magero, J., \& Bittencourt, H. R. (2010). Principais causas de mortalidade na recria e terminação de bovinos de corte. Revista $\begin{array}{lllll}\text { Acadêmica Ciência Agrária } & \text { Ambiental, } & \text { 327-332. }\end{array}$ https://doi.org/10.7213/cienciaanimal.v8i3.10916

Guimarães, P. H. S., Madalena, F. E., \& Cezar, I. M. (2006). Comparative economics of Holstein/Gir F1 dairy female production and conventional beef cattle suckler herds - A simulation study. Agricultural Systems, $\quad 88, \quad 11-124$. https://doi.org/10.1016/j.agsy.2005.02.004

Haddad, C. M., \& Mendes, C. Q. (2010). Manejo da estação de monta, das vacas de cria. In: PIRES, A.V. Bovinocultura de corte. Piracicaba: FEALQ, 13.

Instituto Brasileiro de Geografia e Estatística. Estatística de produção pecuária. IBGE. (2017). Available:

http://www.sidra.ibge.gov.br/bda/pecua/default.asp?t=2\&z=t\&o=24\&u1=1\&u2=1\&u3=1\&u4 $=1 \& u 5=1 \& u 6=1 \& u 7=1$

Instituto Internacional para Sustentabilidade (2015). Análise econômica de uma pecuária mais sustentável. IIS Instituto Internacional para Sustentabilidade. Available: https://www.iis-rio.org/publicacoes/analise-economica-de-uma-pecuaria-mais-sustentavel/

Jorge Junior, J., Cardoso, V. L., \& Albuquerque, L. G. (2006). Modelo bioeconômico para cálculo de custos e receitas em sistemas de produção de gado de corte visando à obtenção de valores econômicos de características produtivas e reprodutivas. Revista Brasileira de Zootecnia, 35, 2187-2196. https://doi.org/10.1590/S1516-35982006000700040

Lobato, J. F. P., Freitas, A. K., Devincenzi, T., Cardoso, L. L., Tarouco, J. U., Vieira, R. M., ... Castro, I. (2014). Brazilian beef produced on pastures: Sustainble and healthy. Meat Science, 98, 336-345. https://doi.org/10.1016/j.meatsci.2014.06.022 
Macedo, M. C. M. (2009). Integração lavoura pecuária: o estado da arte e inovações tecnológicas. Revista Brasileira de Zootecnia, 38, 133-146. https://doi.org/10.1590/S1516-35982009001300015

Marion, J. C. (2010). Contabilidade Rural. 11. ed. São Paulo: Atlas, 238.

Meat \& Livestock Australia - MLA. (2017). Market supplier snapshot Brazil. Available: https://www.mla.com.au/globalassets/mla-corporate/prices-markets/documents/os-markets/re d-meat-market-snapshots/mla-ms_brazil_-snapshot-2017.pdf

Moreira Filho, P. (2004). O papel da transferência de tecnologia no desenvolvimento da produção animal. In: Reunião Anual Da Sociedade Brasileira De Zootecnia, Campo Grande. Anais... Mato Grosso do Sul: Sociedade Brasileira de Zootecnia.

Nantes, J. F. D., \& Scarpelli, M. (2001). Gestão da Produção Rural no Agronegócio. In Batalha, Mario Otávio (Coord.). Gestão Agroindustrial: GEPAI: Grupo de Estudos e Pesquisas Agroindustriais. Vol. 1. 2. ed. São Paulo: Atlas, 28.

Santana, R. A. V. (2012). Desempenho bioeconômico de sistemas intensivos de cria e de ciclo completo por meio de simulação. Brasília, 2012. (Dissertação) Faculdade de Agronomia e Medicina Veterinária, Universidade de Brasília.

Scott, J. F., Scott, J. M., \& Cacho, O. J. (2013a). Whole-farm returns show true profitability of three different livestock management systems. Animal production science, 53, 780-787. https://www.researchgate.net/publication/274877617_Whole-farm_returns_show_true_profit ability_of_three_different_livestock_management_systems

Scott, J. F., Cacho, O. J., \& Scott, J. M., (2013b). Economic risk analysis of different livestock management systems. Animal production science, 53, 788-795. https://www.researchgate.net/publication/275195316_Economic_risk_analysis_of_different_1 ivestock_management_systems

Silva, E. C. (2012). Como Administrar o Fluxo de Caixa das Empresas - Guia de Sobrevivência Empresarial. Edição 6, Editora: Atlas S.A. São Paulo, 360.

Souza, R. M., Coelho, R. W., \& Rodrigues, R. C. (2001). Simulação da produção animal para avaliar o efeito de práticas de manejo na produtividade do gado de corte. In: Reunião anual da sociedade brasileira de zootecnia, Piracicaba. Anais... SBZ.

Torres Junior, A. M., \& Aguiar, G. A. M. (2013). Pecuária de corte no Brasil: potencial e resultados econômicos. In: Encontro de adubação de pastagens da scot consultoria - tec fértil, 1., 2013, Ribeirão Preto. Anais... Bebedouro: Scot Consultoria, 5.

United States Department of Agricuture - USDA. (2018). Livestock and poultry: World markets and trade. Available: www.fas.usda.gov/data/livestock-and-poultry-world-markets-and-trade

United States Department of Agricuture - USDA. (2015). Livestock and poultry: World markets

and trade.

Available: 
https://www.fas.usda.gov/data/livestock-andpoultry-world-markets-and-trade

Velloso, L. (1999). Manejo da reprodução em bovinocultura de corte. In: Bovinocultura de corte: fundamentos da exploração racional. 3.ed. Piracicaba: FEALQ, p.43-60.

Viana, J. G. A., Silveira, V. C. P., \& Vargas, A. F. (2006). Avaliação Econômica em Sistemas Pecuários de Ciclo Completo no Estado Rio Grande do Sul. In: 44th Congress, July 23-27, 2006, Fortaleza, Brazil, Sociedade Brasileira de Economia, Administração e Sociologia Rural (SOBER).

Yokoyama, L. P., Filho, A. V., Balbino, L., Oliveira, I. P. \& Barcellos, A. O. (1999). Avaliação econômica de técnicas de recuperação de pastagens. Pesquisa Agropecuária, Brasília, 34, 1335-1345. https://doi.org/10.1590/S0100-204X1999000800003

Zdanowicz, J. E. (2001). Planejamento financeiro e orçamentário. 2. ed. Porto Alegre: Sagra Luzzatto, 303.

Zimmer, A. H., Macedo, M. C. M., Kichel, A. N., \& Almeida, R. G. (2012). Degradação, recuperação e renovação de pastagens. Campo Grande: Embrapa Gado de Corte, 46.

\section{Copyright Disclaimer}

Copyright for this article is retained by the author(s), with first publication rights granted to the journal.

This is an open-access article distributed under the terms and conditions of the Creative Commons Attribution license (http://creativecommons.org/licenses/by/4.0/). 